\title{
Chemical Control of the Grape Vine Bud Mite, Eriophyes vitis (Pagenstecher) $)^{1}$
}

\author{
C. A. DE KLERK
}

Viticultural and Oenological Research Institute, Private Bag X5026, 7600 Stellenbosch, Republic of South Africa.

Submitted for publication: October 1984

Accepted for publication. December 1985

Key words: Eriophyes vitis, grape vine bud mite, control

The writer wishes to thank the following persons for making experimental plots available, and for their kind co-operation: Mr. Niel Fyfer, Adamsfontein, Malmesbury; Mr. Jan Rabie, Nuwerus, Worcester; Mr. Niel Malan, Diamant, Paarl en Mr. J. D. Kirsten, Vredehof, Paarl.

\begin{abstract}
Various chemicals were tested in field trials for the control of the grape vine bud mite. Chlorobenzilate (Akar) $50 \%$ ec at 50 $\mathrm{ml} / 100 \ell$ water and propoxur (Unden) $20 \%$ ec at $125 \mathrm{ml} / 100 \ell$ water resulted in satisfactory control. The best results were obtained with three applications per season at 14 day intervals, starting at bud burst. At least $500 \mathrm{ml}$ spray mixture per vine must be applied.
\end{abstract}

The grape vine bud mite which attacks the buds and the well-known erinose (blister) mite which attacks the leaves, belong to the same species, i.e. Eriophyes vitis (Pagst.). However, they are regarded as biologically different strains because of the difference in their patterns of behaviour as well as the damage they cause (Smith \& Stafford, 1948). Erinose mites overwinter in the buds and migrate to the leaves during spring. At the end of summer, after having multiplied, they return to the buds to overwinter. In the case of bud mite, the mites do not migrate to the leaves, but penetrate the buds of the new shoots where they feed, multiply and overwinter. The erinose mites feed on the ventral side of the leaf and cause distinct galls on the dorsal surface, which inhibit the normal physiological functions of the leaves. The bud mite causes smaller and deformed leaves at the base of the shoot, smaller and deformed shoots as well as stunted and deformed bunches. A severe infestation could kill the primary buds, stimulating the secondary buds, which are mostly infertile in many cultivars (De Klerk, 1980).

The bud mite problem is increasing in practically all South African viticultural areas and because of complaints by numerous farmers that present chemical control measures are unsatisfactory, two field experiments were carried out to test the efficacy of existing registered chemicals as well as other chemicals against the pest. According to the literature there is no agreement regarding the precise time of application (Smith \& Stafford, 1948; Kido \& Stafford, 1955; Avidov \& Harpaz, 1969; Whitehead et al., 1978). It is generally recommended locally that the first spray application should be made at a shoot length of $100 \mathrm{~mm}$ (De Klerk, 1978), but recent biological studies have shown that the majority of mites are present outside the bud during and shortly after budding, and are thus unprotected against pesticides at this time (G. B. Dennill, 1982 - personal communication). It is also generally recommended that treatment at a shoot length of $100 \mathrm{~mm}$ be followed by a further application 14 days later. There is no certainty whether this is the best recommendation nor what volume of spray mixture should be applied per vine. A further field experiment was conducted to clarify these aspects.

\section{MATERIALS AND METHODS}

A. Efficacy of pesticides: An experiment consisting of the following treatments was carried out in a severely bud mite-infested Vitis vinifera L. cv. Palomino (White French) vineyard in the Worcester area, trelised according to the Perold system.

(a) Untreated control

(b) Chlorobenzilate (Akar) $50 \%$ ec (emulsifiable concentrate) at $50 \mathrm{ml} / 100 \mathrm{l}$ water

(c) Oxamyl (Vydate) $24,5 \%$ sol. (solution) at $400 \mathrm{ml} / 100 \ell$ water

(d) Propoxur (Unden) $20 \%$ ec at $125 \mathrm{ml} / 100 \mathrm{l}$ water.

Each treatment was replicated five times in a randomised block design. Each plot consisted of three rows of 12 vines each, and observations were made at the six central vines. The chemicals were applied by means of a knapsack spray pump at the $100 \mathrm{~mm}$ shoot length stage (September) and repeated 14 days later, applying approximately 400 $\mathrm{ml}$ spray mixture per vine during 1978 and 1979.

One shoot per vine was collected from each of the six data vines per plot and the first four buds on each shoot examined microscopically for the presence of bud mite. These observations were made before as well as after treatment during July (winter) 1978, 1979 and 1980.

Another experiment was carried out in the Malmesbury area in a bushvine vineyard (Palomino) which was severly infested with bud mite. Treatments were as follows:

(a) Untreated control

(b) Chlorobenzilate (Akar) $50 \%$ ec at $50 \mathrm{ml} / 100 \mathrm{\ell}$ water

(c) Monocrotophos (Azodrin) $40 \%$ sol. at $250 \mathrm{ml} / 100 \ell$ water

(d) Chlorobenzilate (Akar) $50 \%$ ec at $25 \mathrm{ml} / 100 \mathrm{\ell}$ water plus endosulfan (Thiodan) $47 \%$ wp at $50 \mathrm{~g} / 100 \ell$ water.

The layout of the experiment, as well as the methods and time of observation, was similar to that described for the experiment at Worcester. The chemicals were, however, applied by means of a high volume spray pump with hand spray guns at a pressure of $1000 \mathrm{kPa}$. Treatments were applied three times during the season, viz. at $100 \mathrm{~mm}$

${ }^{1}$ Presented at the 7th Congress of the South African Society for Enology and Viticulture, Cape Town 1983.

\section{S. Afr. J. Enol. Vitic., Vol. 6. No. 11985}


shoot length, 14 days later, and again 14 days after the second application. Applications were made at these intervals during 1978 and 1979 using approximately $800 \mathrm{ml}$ of spray mixture per vine. Yield mass was measured for each plot during 1979, 1980 and 1981.

B. Application of pesticide: An experiment was carried out in a bushvine vineyard (Palomino) severely infested with bud mite in the Paarl area. The vines were sprayed with chlorobenzilate (Akar) $50 \%$ ec at $50 \mathrm{ml}$ per $100 \ell$ water at a pressure of $800 \mathrm{kPa}$, by means of a high volume spray pump equipped with hand guns. Application times and volume of spray mixture were as follows:

(a) Untreated control

(b) At $100 \mathrm{~mm}$ shoot length stage and again 14 days later at a rate of $750 \mathrm{ml} / \mathrm{vine}$.

(c) At $100 \mathrm{~mm}$ shoot length stage and again 14 days later at a rate of $500 \mathrm{ml} /$ vine.

(d) At $100 \mathrm{~mm}$ shoot length stage and again 14 days later at a rate of $250 \mathrm{ml} /$ vine.

(e) At $100 \mathrm{~mm}$ shoot length stage and again 14 days later at a rate of $125 \mathrm{ml} / \mathrm{vine}$.

(f) Three applications at 14 day intervals commencing at the $100 \mathrm{~mm}$ shoot length stage at a rate of $500 \mathrm{ml} / \mathrm{vine}$.

(g) At the budding stage and again after 14 days at a rate of $500 \mathrm{ml} / \mathrm{vine}$.

(h) Three applications at 14 day intervals commencing at the budding stage at a rate of $500 \mathrm{ml} /$ vine.

Each treatment was replicated five times in a randomised layout with each plot consisting of six vines in a row. Replications were separated from one another by at least four vines in the row and a single adjacent row. Applications were made in 1981 only. One shoot per vine was collected from the six data vines per plot and the first four buds of each shoot were examined microscopically for the presence of bud mite. These observations were made before as well as after treatment during July 1981 and 1982.

Additional observations on the chemical control of bud mite were also made where a producer treated large vineyard blocks. Chlorobenzilate $50 \%$ ec was applied with a mist blower at approximately $500 \mathrm{ml}$ spray mixture per vine, at the $20 \mathrm{~mm}$ shoot length stage, 12 days later and again 14 days later. The percentage of vine buds infested with bud mite was determined microscopically before as well as after treatment during July 1980 and 1981 .

\section{RESULTS AND DISCUSSION}

A. Efficacy of pesticides: The effect of the chemical treatments on the percentage bud infestation by bud mite in the Worcester experiment is shown in Table 1. Chlorobenzilate, oxamyl and propoxur do not differ in their efficacy and reduced the bud mite population significantly compared to the untreated control during both seasons after treatment. While chlorobenzilate and propoxur are registered for the control of bud mite, oxamyl is not, and is also more expensive. Although control was obtained following only one season's treatment (1979), improved control was obtained by applying the treatment for two successive seasons (1980). As bud mite was still present after two seasons, it appears that pesticide sprays should be applied for more than two successive seasons.
TABLE 1

The effect of chemical treatments on the percentage bud infestation of Palomino by vine bud mite in the Worcester area (120 buds per treatment)

\begin{tabular}{l|c|c|c}
\hline \multirow{2}{*}{ Treatment } & \multicolumn{3}{|c}{ Percentage infestation } \\
& $1978^{1}$ & $1979^{2}$ & $1980^{3}$ \\
\hline Untreated control & 75,5 & 85,0 & 83,3 \\
Chlorobenzilate & 67,8 & 40,0 & 29,2 \\
Oxamyl & 72,2 & 47,5 & 38,3 \\
Propoxur & 68,9 & 45,8 & 26,7 \\
\hline LSD (P =0,05) & \multirow{2}{*}{ NS } & 25,7 & 26,4 \\
$\quad(P=0,01)$ & & 33,7 & 34,6 \\
\hline
\end{tabular}

13 Months before treatment

29 Months after first treatment

39 Months after second treatment

The effect of the chemical treatments on the percentage bud infestation by bud mite in the Malmesbury experiment is shown in Table 2. Chlorobenzilate and the chlorobenzilate/endosulfan mixture significantly reduced the bud mite population in comparison with the control during 1979, and these treatments as well as monocrotophos resulted in highly significantly less infestation than the control during 1980. As in the Worcester experiment it is again evident that chlorobenzilate provides effective control of bud mite. Monocrotophos is an extremely toxic and wide spectrum chemical which can be harmful to the natural enemies of other pests, while a mixture of chlorobenzilate and endosulfan has no advantage over a treatment with chlorobenzilate alone. Furthermore, these results indicate that spraying should be carried out for more than two successive seasons, as in the case of the Worcester experiment.

TABLE 2

The effect of chemical treatments on the percentage of bud infestation of Palomino by vine bud mite in the Malmesbury area (120 buds per treatment)

\begin{tabular}{l|c|c|c}
\hline \multirow{2}{*}{ Treatment } & \multicolumn{3}{|c}{ Percentage infestation } \\
& $1978^{1}$ & $1979^{2}$ & $1980^{3}$ \\
\hline Untreated control & 53,3 & 55,8 & 70,8 \\
Chlorobenzilate & 48,3 & 19,2 & 12,5 \\
Monocrotophos & 50,7 & 36,7 & 22,5 \\
Chlorobenzilate & & & \\
plus endosulfan & 57,7 & 22,5 & 19,2 \\
\hline LSD (P = 0,05) & \multirow{2}{*}{ NS } & 29,6 & 26,7 \\
$\quad$ P $=0,01)$ & & 38,8 & 35,0 \\
\hline
\end{tabular}

13 Months before treatment

29 Months after first treatment

39 Months after second treatment

The average yield per plot of six vines for each treatment in the Malmesbury experiment is shown in Table 3. Although not significant, an average improvement in yield of $35 \%$ and $30 \%$ was obtained with chlorobenzilate in comparison with the untreated control during the 1980 and1981 seasons respectively. Replications for the experiment were originally chosen according to the level of bud mite infestation, resulting in larger than normal variation in growth and yield which could possibly be the reason why the improvement in yield was not statistically significant. 
TABLE 3

The effect of chemical treatments for bud mite control on yield of Palomino in the Malmesbury area (average/6 vines)

\begin{tabular}{l|c|c|c}
\hline Treatment & 19791 & $\begin{array}{c}\text { Yield }(\mathrm{kg}) \\
1980^{2}\end{array}$ & $1981^{3}$ \\
\hline Untreated control & 22,1 & 15,2 & 18,5 \\
Chlorobenzilate & 18,5 & 20,5 & 24,0 \\
Monocrotophos & 13,4 & 13,1 & 18,3 \\
Chlorobenzilate & 17,9 & 16,3 & 18,6 \\
plus endosulfan & 11,9 & 13,7 & 15,0 \\
\hline LSD (P = 0,05) & 15,6 & 17,9 & 17,2 \\
\hline \multicolumn{1}{|c|}{$(\mathbf{P}=0,01)$} & & &
\end{tabular}

14 Months after first treatment

24 Months after second treatment

${ }^{3} 16$ Months after second treatment

B. Application of pesticides: The trial at Paarl showed that $750 \mathrm{ml} /$ vine and $500 \mathrm{ml} /$ vine did not differ significantly from each other, but that significantly better control was obtained with these two treatments than with $250 \mathrm{ml} /$ vine and $125 \mathrm{ml} /$ vine (Table 4). According to these results at least $500 \mathrm{ml}$ of spray mixture should be applied per vine to obtain the most effective control of bud mite.

TABLE 4

The effect of volume of spray mixture of chlorobenzilate applied at the $100 \mathrm{~mm}$ shoot length stage and 14 days later on the percentage bud infestation of Palomino by vine bud mite in the Paarl area (120 buds per treatment)

\begin{tabular}{|c|c|c|c|}
\hline \multirow{2}{*}{ Treatment } & \multicolumn{2}{|c|}{$\begin{array}{l}\text { Percentage } \\
\text { infestation }\end{array}$} & \multirow[t]{2}{*}{ Control $(\%)$} \\
\hline & $1981^{1}$ & $1982^{2}$ & \\
\hline $\begin{array}{l}\text { Untreated control } \\
750 \mathrm{ml} / \text { vine } \\
500 \mathrm{ml} / \text { vine } \\
250 \mathrm{ml} / \text { vine } \\
125 \mathrm{ml} \text { /vine }\end{array}$ & $\begin{array}{l}81,7 \\
81,7 \\
79,2 \\
79,2 \\
80,0\end{array}$ & $\begin{array}{l}76,7 \\
26,7 \\
32,5 \\
50,8 \\
57,5\end{array}$ & $\begin{array}{r}6 \\
67 \\
59 \\
36 \\
28\end{array}$ \\
\hline $\begin{array}{r}\operatorname{LSD}(\mathbf{P}=0,10) \\
(\mathbf{P}=0,05) \\
(\mathrm{P}=0,01)\end{array}$ & NS & $\begin{array}{l}11,8 \\
20,5 \\
25,6\end{array}$ & \\
\hline
\end{tabular}

12 Months before treatment

${ }^{2} 10$ Months after treatment

According to Table 5, two applications of chlorobenzilate commencing during budding did not render significantly better control than the present recommendation of two sprays commencing at the $100 \mathrm{~mm}$ shoot length stage. Three applications from the $100 \mathrm{~mm}$ shoot length stage were also not significantly better than the previous two treatments. Where three treatments were applied commencing at the budding stage, significantly better contol was obtained in comparison with the three previous treatments.

From these results it appears that the application of three sprays starting at the $100 \mathrm{~mm}$ shoot length stage at 14 day intervals, commences too late because by the third application the mites have probably penetrated the new buds. In the case of three applications commencing from the budding stage, the third application is still effective against migrating mites.
TABLE 5

The effect of time of application and number of spray applications per season of chlorobenzilate ( $500 \mathrm{ml}$ spray mixture/vine) on the percentage bud infestation by vine bud mite in the Paarl area (120 buds per treatment)

\begin{tabular}{l|c|c|c}
\hline & \multicolumn{2}{|c|}{$\begin{array}{c}\text { Percentage } \\
\text { infestation } \\
\text { Treatment }\end{array}$} & $\begin{array}{c}\text { Control } \\
(\%)\end{array}$ \\
\hline Untreated control & $1981^{1}$ & $1982^{2}$ & \\
$100 \mathrm{~mm}+14$ days & 81,7 & 76,7 & 6 \\
Bud + 14 days & 79,2 & 32,5 & 59 \\
100 mm + 14 days + 14 days & 80,0 & 38,3 & 52 \\
Bud + 14 days + 14 days & 79,8 & 28,3 & 65 \\
\hline LSD (P = 0,10) & NS & 13,3 & 83 \\
$\quad(P=0,05)$ & & 11,1 & \\
$\quad(P=0,01)$ & & 24,0 & \\
\hline
\end{tabular}

12 Months before treatment

${ }^{2} 10$ Months after treatment

Results of the additional observations in various blocks are given in Table 6 . Although the data could not be processed statistically, it clearly shows that effective control ( $77 \%$ average) can be obtained with large scale applications, provided that the correct time of application, number of applications and minimum volume of spray mixture per vine are adhered to.

TABLE 6

The effect of chlorobenzilate applied on a commercial scale on the percentage of vine buds infested with bud mite ( 24 buds per cultivar)

\begin{tabular}{l|c|c|c}
\hline Cultivar & \multicolumn{2}{c}{$\%$ infested vine buds } \\
& $\begin{array}{c}\text { pre-treatment } \\
1980\end{array}$ & $\begin{array}{c}\text { post-treatment } \\
1981\end{array}$ & \\
\hline Dan-ben-Hannah & 56,2 & 0,0 & 100 \\
Dan-ben-Hannah & 35,0 & 4,2 & 88 \\
Queen of the & & & 87 \\
Vineyard & 62,5 & 8,3 & 72 \\
Waltham Cross & 75,0 & 21,0 & 69 \\
Waltham Cross & 93,8 & 29,2 & 57 \\
Waltham Cross & 86,5 & 37,5 & 65 \\
Waltham Cross & 82,4 & 29,2 & \\
\hline
\end{tabular}

\section{CONCLUSIONS}

It is clear that the two chemicals registered for the control of bud mite, viz. chlorobenzilate and propoxur, provided effective control. The best control was obtained with three applications per season, at 14 day intervals, starting at bud burst. At least $500 \mathrm{ml}$ of spray mixture per vine must be applied.

Although the results of the initial trial indicated that the treatment should be applied for more than two successive seasons, it now appears that only two seasons should be sufficient for economical control if the above recommendations are carried out correctly. In the experiment in which this treatment was applied, $83 \%$ control of the bud mite infestation was obtained after only one season. Furthermore, the results show that with these recommendations successful control $(77 \%$ average after the first season) was also obtained in practice with large scale applications and with a mist blower. As a consider- 
able amount of spray mixture is lost when a mist blower is used during the budding stage, the use of hand guns is recommended. If this is not possible the nozzles of the mist blower should be adjusted so that most of the spray mixture is directed onto the buds and shoots.

\section{LITERATURE CITED}

AVIDOV, Z. \& HARPAZ, I., 1969. Plant pests of Israel. Israel University Press, Jerusalem.
DE KLERK, C. A., 1978. Chemical control of insect and other pests of wine and dried grapes. Farming in South Africa, Oenology and Viticulture. Leaflet F. 10.

DE KLERK, C. A., 1980. The vine bud mite and erinose mite. Farming in South Africa, Oenology and Viticulture. Leaflet F. 14.

KIDO, H. \& STAFFORD, E. M., 1955. The biology of the grape bud mite Eriophyes vitis (Pgst.). Hilgardia 24, 119-142.

SMITH, L. M. \& STAFFORD, E. M., 1948. The bud mite and the erineum mite of grapes. Hilgardia 18,317-334.

WHITEHEAD, V. B., RUST, D. J., PRINGLE, K. A. \& ALBERTSE, G., 1978. The bud infesting strain of the grape leaf blister mite, Eriophyes vitis (Pgst.) on vines in the Western Cape Province. J. Ent. Soc. sth. Afr. 41, 9-15. 